\title{
Managerial Skill development for Self-help group members in Cuddalore District, Tamilnadu
}

Dr.N.Panchanatham, Professor, Business Administration, Annamalai University.

Dr.M.Jeyakuraman, Associate Professor, Business Administration, Annamalai University. Special Assistance Programme (SAP)

https://doi.org/10.51705/AIJBSR.2019.v11i01.006

SAP- Special Assistance Programme is sanctioned to Department Of Business Administration, Annamalai University during the year 2013 for the period of five years 2013 -2018. SAP -DRS 1 is sanctioned by UGC to academic institutions who have the eligibility to receive.

Dept. Of Business Administration applied for SAP got selected in the Interview conducted by UGC. The Co-ordinator Dr.N.Panchanatham and Deputy co-ordinator Dr.M.Jeyakumaran faculty members of the department carried out the SAP programme. The department was sanctioned Rs.55 lakhs under SAP programme by UGC. Recurring grant of Rs33 lakhs for the period of five years and Nonrecurring grant of Rs.22 lakhs.

The recurring grant was utilised by the department by conducting a National level seminar and purchase of Books for the Library and non recurring grant is was utilised in built up of an $\mathrm{Hi}-$ tech computer lab and Self-help-group Training hall for the department.

The SAP programme is intended with an objective to impart Managerial skill development for SelfHelp-Group members of Cuddalore district. The department of Business administration is aimed at to fully utilise the resources for the successful completion of the SAP project. 